удК $\quad 327(497.1: 450) " 1948 "$

342.8(450)"1948"

324(450)"1948"

DOI https://doi.org/10.31212/tokovi.2021.3.dra.71-88

Оригинални научни рад

Примљен: 20. 5. 2021.

Прихваћен: 12. 11. 2021.

\author{
Petar DRAGIŠIĆ \\ Institute for Recent History of Serbia, Belgrade \\ petardragisic@gmail.com
}

\title{
Yugoslavia and General Election in Italy in 1948*
}

ABSTRACT: The paper deals with Yugoslav perceptions of the 1948 general election in Italy. The research focuses primarily on reports of the Yugoslav legation in Rome, which closely monitored the election campaign as well as the consequences of this watershed in the Cold War phase of Italian history. The Yugoslav sources cast a light on the strategies of the principal protagonists in the Italian political turmoil in April 1948.

KEY WORDS: election, 1948, Italy, Yugoslavia, Togliatti

The fall of Benito Mussolini's regime in July 1943 and the installation of Badoglio's government opened the door to establishing an anti-fascist post-war system in the Apennine Peninsula. The major components of this provisional establishment were the Christian Democracy (Democrazia Cristiana) and the Italian Communist Party (Partito Comunista Italiano). Nevertheless, this peculiar coalition did not stand the test of time since Italy's pro-Western orientation and the escalation of the Cold War tensions dictated considerable modifications of the Italian political scene. The expulsion of the Italian Communist Party from the ruling coalition in 1947 signaled the full-scale confrontation between Communists and Catholics, which de facto took place in the general election in April 1948. ${ }^{1}$

\footnotetext{
* This paper was written as a result of the work at the Institute for Recent History of Serbia, funded by the Serbian Ministry of Education, Science and Technological Development, through the Agreement on Realization and Funding of Scientific Research NIO in 2021 no. 451-03-9/2021-14/200016 of February 5, 2021.

1 Paul Ginsborg, Storia d'Italia dal dopoguerra a oggi, (Torino: Piccola Biblioteca Einaudi Storia, 2006); Giuuseppe Mammarella, L'Italia contemporanea (1943-2011),
} 
Given the difficult relations between Rome and Belgrade in the first post-war years, primarily due to the Trieste question, ${ }^{2}$ the Yugoslav diplomats closely monitored the dramatic political developments in the Appenine peninsula, including the momentous election in Italy, in April 1948, which radically determined the political landscape of post-war Italy. The Yugoslav observers were carefully analyzing not only relations between the domestic protagonists, but also the role of principal international players in Italian affairs following the Second World War.

In August 1947 the Yugoslav legation in Rome ${ }^{3}$ summed up the key features of Italian politics prior to the general election in Italy in 1948. The analysis of the Yugoslav legation in Rome, composed in September 1947, payed particular attention to the expulsion of the Italian communists (Partito Comunista Italiano) and socialists (Partito Socialista Italiano) from De Gasperi's government in the spring of 1947 . This radical move by De Gasperi was viewed as evidence of a bitter class struggle in Italy and signal of the Christian Democrats' orientation towards gathering "the monarchist and pro-fascist reaction in a struggle against the forces of democracy and the proletariat". According to the authors of the Yugoslav report, the anti-communist campaign, launched by the Italian bourgeoisie "linked with American trusts", the Vatican, and by reactionary, monarchist and neo-fascist groups, came as a reaction to the success of the Communist Party in

(Bologna, Società editrice il Mulino: 2012); Hans Woller, Geschichte Italiens im 20. Jahrhundert, (München: C. H. Beck, 2010); Miodrag Lekić, Istorija Italije. Od Kavura do Montija (1861-2011), (Beograd: Smart studio, 2013); Petar Dragišić, Šta smo znali o Italiji. Pogledi iz Beograda na Italiju 1955-1978, (Beograd: Institut za noviju istoriju Srbije, 2019).

2 On the Trieste question and the Yugoslav-Italian relations, see (among others): Miljan Milkić, Tršćanska kriza u vojno-političkim odnosima Jugoslavije sa velikim silama 1943-1947, (Beograd: Institut za noviju istoriju Srbije, 2012); Bojan Dimitrijević, Dragan Bogetić, Tršćanska kriza 1945-1954. Vojno-politički aspekti, (Beograd: Institut za savremenu istoriju, 2009); Francesca Rolandi, Con ventiquattromila baci. L'influenza della cultura di massa italiana in Jugoslavia (1955-1965), (Bologna: Bononia University Press, 2015; Saša Mišić, Pomirenje na Jadranu. Jugoslavija i Italija na putu ka Osimskim sporazumima iz 1975. godine, (Beograd: Fakultet političkih nauka, 2018); Bogdan C. Novak, Trieste 1941-1954. La lotta politica, etnica e ideologica, (Mursia, 2013); Petar Dragišić, “Tito's War after the War: Yugoslav Territorial Claims against Austria and Italy, 1945-1949", The Alps-Adriatic Region. International and Transnational Perspectives on a Conflicted European Region, eds Wolfgang Mueller, Karlo Ruzicic-Kessler, Philipp Greilinger, (Wien: New Academic Press, 2018), 31-51.

3 On activities of the Yugoslav legation in Rome in the first post-war years, see: Miljan Milkić, „Jugoslovensko poslanstvo u Rimu 1947-1951“, Jugoslovenska diplomatija 1945-1961, zbornik radova, ur. Slobodan Selinić, (Beograd: Institut za noviju istoriju Srbije, 2012), 115-134. 
the 1947 Sicilian regional election. Besides, in its analysis of Italian political affairs in 1947, the Yugoslav legation in Rome did not underestimate the European, i.e. the global Cold War context, underlining that the expulsion of the communists from De Gasperi's government was not an exclusively Italian phenomenon, given the analogous processes in Belgium and France, which reinforced the belief of the Yugoslav diplomats in the Italian capital that Washington ("American imperialism") played a major role in these political maneuvers. Nevertheless, the Yugoslav diplomatic representatives in Rome emphasized the contrast between the political situation in Italy and France, given the futile attempt of Italian "reaction" to shatter the unity of the Italian working class, i.e. the alliance between the communists and the Socialist Party of Italy. Besides, the Yugoslav report commended the influence and monolithic structure of the Italian Communist Party, which penetrated deep into the Italian society. ${ }^{4}$

The Yugoslav diplomats particularly focused on Saragat's party, which splintered from the Socialist Party, underlining its role in broadening the base of De Gasperi's Christian Democracy government. Moreover, the Yugoslav report sharply criticized Giuseppe Saragat for being under Washington's control ("American hireling"), an implacable enemy of communists and a Trotskyist working against the unity of the Italian working class. However, the Yugoslav analysts forecasted a grim future for Saragat underlining his waning influence in his own party: "In any case, Saragat's ambitions to become the new Blum (André Léon Blum - P. D.) have no chance, and in the upcoming election, he could greatly disappoint his American masters." ${ }^{5}$

The Yugoslav observers of Italian affairs were well aware of the global context of the political tensions in the Apennine Peninsula in 1947/1948. The report of September 1947 stressed the massive American support for Italian "forces of reaction" claiming that the "Italian problem" was high on the agenda of the campaign of "American imperialism". Consequently, the authors of the report anticipated a fierce struggle between "the progressive forces of the Italian people" and its powerful and unscrupulous enemy. In this regard, the document underlined the American military presence in Italy and emphasized the regional importance of the epic political and ideological struggle in Italy: "Great struggles are on the horizon in Italy, the outcome of which will be of crucial importance

\footnotetext{
4 Arhiv Jugoslavije (Archives of Yugoslavia - AJ), Kabinet maršala Jugoslavije (836), 1-3-b/322, Poslanstvo FNRJ (Rim) - Ministarstvu vanjskih poslova FNRJ, 5. 9. 1947. 
for the future of democracy in this part of Europe. Today, the Apennine Peninsula is one of the most vulnerable places that America is focusing on. That is why the fight will be difficult and long-lasting."

A month later, in October 1947, the Yugoslav envoy in Rome, Mladen Iveković, reiterated these evaluations in a report on the impact of the founding conference of the Cominform on the political situation in Italy. The Yugoslav diplomat severely criticized in particular Giuseppe Saragat and the American interference in Italian internal affairs. In Ivekovic's report Saragat was portrayed as "the loudest megaphone of the Italian reaction and American agents", whose key task was destroying the unity of the Italian working class. ${ }^{7}$ The report placed a strong emphasis on American interference in the Italian politics of the early post-war years, i.e. their support for Christian democrats and its struggle against the Popular Democratic Front in Italy: "The American imperialists will now make every effort to prevent the strengthening and victory of the Democratic Front in Italy. They will invest significant funds for this purpose. It should be expected that the USA will now interfere in Italian affairs with more risk. They will give De Gasperi certain loans, and in return they will get him to sign the Treaty of Friendship, Commerce and Navigation, which will put Italy in an inferior position to the USA." ${ }^{8}$

In a conversation with Mladen Iveković in the Summer of 1947, the leader of the Partito Comunista Italiano, Palmiro Togliatti, updated his Yugoslav interlocutor on the political situation in Rome briefing him on the position of the leading figures of Italian politics. Togliatti underlined the influence of "agents of the USA and the Vatican" on his major political rival, Catholic leader Alcide de Gasperi, and consequent attempts of the USA to reinforce his precarious position. Togliatti's observations of Saragat were less political and more psychological, since he described the leader of the Socialist Party of Italian Workers party as mentally unbalanced and insane. According to Togliatti, Pietro Nenni had contributed to maintaining the unity of the Italian working class. Nevertheless, the leader of Italian communists did not place blind trust in his socialist ally. In the conversation with Mladen Iveković he portrayed Nenni as an unreliable partner, stressing his contacts with the British Labour Par-

\footnotetext{
6 Ibid.

7 AJ, 836, 1-3-b/322, Poslanstvo FNRJ (Rim), Izveštaj o odjeku Varšavske konferencije devet Kompartija, 10. 10.1947.

8 Ibid.
} 
ty and other social democratic parties abroad. On the other hand, Togliatti expressed his profound admiration for Lelio Basso, despite Basso's intention to "absorb" communists, pointing out his leadership and considerable influence in the Italian Socialist Party. ${ }^{9}$

In the conversation with Mladen Iveković Togliatti payed particular attention to the major patrons of Christian Democrats - the USA and the Vatican. In this regard, the leader of Italian communists underlined the omnipotence and financial power of the Holy See, i.e. the presence of its capital in diverse lucrative industries in the Apennine Peninsula: "There is no need to waste words on the power of the Vatican in Italy. The fact is that today the Vatican is becoming a first-class capitalist factor, not only ideologically, which is a well-known fact, but also by entering the economy, trade and industry. The Vatican rules the black market, opens banks, sells groceries, buys stocks, shops, houses. The influence of the Vatican is strong, especially on the Italian peasants, the middle class and women. Textile workers are under a very strong clerical influence, due to a large percentage of women among textile workers." ${ }^{10}$

Given the intensification of the "class struggle" in Italy, in the conversation with Mladen Iveković Togliatti ruled out the possibility of a peaceful solution of Italian political and social crisis. However, he refrained from forecasting the outcome of this epic conflict by pointing out the outstanding financial capacities of the Italian bourgeoisie. Besides, the leader of Italian communists openly criticized his own party, underlining its major weaknesses, like the deficient Marxist education of the Party's cadre and unexperienced journalists in the communist press. Despite these problems, Togliatti expressed optimism about the election results. ${ }^{11}$

In February 1948 Mladen Iveković met Togliatti again and composed a brief record of this conversation. In this document, forwarded to Josip Broz Tito, the Yugoslav envoy in Rome strongly criticized the political tactic of Togliatti and his Party regarding the 1948 election. Iveković particularly condemned Togliatti's orientation towards coming to power through elections. The Yugoslav diplomat did not share Togliatti's opinion, that conditions in Italy were favorable for installing a Pol-

9 AJ, 836, 1-3-b/322, Poslanstvo FNRJ (Rim), Povjerljivi izvještaj poslanika FNRJ u Rimu Mladena Ivekovića Maršalu Jugoslavije Josipu Brozu Titu o razgovoru sa generalnim sekretarom KP Italije Palmirom Togliattiem, Rim, 10. 9. 1947. Ibid.

11 Ibid. 
ish-style democracy in Italy, arguing that such forms of "new democracies" had been developed under exceptional circumstances, which included armed struggle or (sometimes exclusively) the activities of the Red Army: "There were no cases where the countries of the new democracy arose from elections (...) I do not see the possibility of the Italian working class and democratic elements to seize power and carry out revolutionary changes without a struggle against the most reactionary part of the bourgeoisie." ${ }^{12}$

Several weeks prior to the elections, the Yugoslav legation in Rome summed up the political situation in Italy, focusing on favoritism towards the Christian Democracy during the election campaign. The authors of this concise document asserted that the entire state apparatus, including the police, supported De Gasperi's party. ${ }^{13}$

In late April 1948, the Yugoslav legation in Rome composed a comprehensive report on the general election in Italy, focusing on the conduct of the key direct and indirect participants in the Italian political tumult. The author of the report sharply criticized American interference in the Italian election of 1948, focusing on the statements of American top politicians about political developments in the Apennine Peninsula (president Truman, state secretary George Marshall, under secretary of state Robert Lovett, the US ambassador to Italy James Dunn), as well as discussions at several international meetings (the Conference of Sixteen in Paris, Conference in Brussels, Pan-American Conference in Bogota). Besides, the document underlined the substantial American financial assistance for De Gasperi, massive propaganda campaign in support of the Italian "reaction", including special radio programs, activities of the society Progresso Italo-Americano, which distributed thousands of letters to Italian citizens, as well as proclamations of "failed politicians" in exile (Vladko Maček, Stanisław Mikołajczyk, Georgi Dimitrov Gemeto and Milan Gavrilović) warning Italian voters against voting for the communists and the Democratic Front. This extensive campaign of the USA in Italy in the spring of 1948 was taken as evidence of Italy's importance for extending Anglo-American influence in the whole Mediterranean, in-

12 AJ, Savez komunista Jugoslavije (507), Komisija za međunarodne odnose i veze (IX), 48/XIV/13, Poslanstvo FNRJ (Rim), Izvještaj poslanika FNRJ u Rimu Mladena Ivekovića Maršalu Jugoslavije Josipu Brozu Titu o razgovoru sa generalnim sekretarom KP Italije Palmirom Togliattiem, Rim, 10. 2. 1948.

13 AJ, 836, 1-3-b/332, Poslanstvo FNRJ (Rim), Rezime izveštaja poslanstva u Rimu od 1. 3. 1948. 
cluding France and Greece: "It was clear that (...) developments in Italy would be of great importance for the positions of Anglo-Americans in the Mediterranean, for developments in France, Greece, etc. Only in this way can the brutal character of the US interference and their support for the victory of the Right and fascism in Italy be explained. The vital interests of American imperialism are at stake. It was a policy built on the idea of the domination of American imperialism over Europe. And that is why huge funds flowed from America, which were supposed to ensure De Gasperi's victory." ${ }^{14}$

The Yugoslav legation in Rome payed particular attention to speeches and statements of Harry Truman and George Marshal on the election in Italy. Truman's speech given on 17 March was interpreted in the Yugoslav document as a threat of US military intervention in case of a communist victory in Italy. In addition, the report quoted Marshall's speech delivered two days later, in which the US state secretary openly warned that if the Democratic Front won, Italy would be banned from participating in the US relief program. Consequently, the Yugoslav analysis reads, the Right extensively used this threat as a mighty propaganda tool in the election campaign ("If communists come to power, Italy will not receive American relief anymore.") ${ }^{15}$

The American interference in the election campaign in Italy was also severely criticized in a comprehensive analysis of the Department for international relations of the Communist Party of Yugoslavia. The document comprised a brief overview of the American support for De Gasperi's party: "The Americans are very interested in the outcome of the election and are trying to help De Gasperi in all possible ways - from boarding the American fleet in Italian ports in order to intimidate and give support, to threats they would stop sending aid according to the Marshall Plan and the latest provocations regarding Trieste. US officials came to Italy to participate in the election campaign and US Ambassador Dunn himself takes part in rallies. Leaflets against the PCI and the Democratic Front are printed in America and then distributed all over Italy". ${ }^{16}$

The author of the report of the Yugoslav legation in Rome focused on two international issues, which coincided with the 1948 general election in Italy and which were extensively used by the Italian "reaction" in

14 AJ, 836, 1-3-b/332, Poslanstvo FNRJ (Rim), Izbori za parlament i senat 18. 4. 1948.

15 Ibid.

16 AJ, 507, 48/XIII/21, Italija (1948). 
the final stage of the election campaign - the coup d'etat in Czechoslovakia in late February 1948 and the Tripartite declaration (USA, Great Britain, France) on the Trieste question. According to the document of the Yugoslav legation in Rome, the communist takeover in Prague was heavily exploited in the anticommunist campaign in Italy, providing the pretext for fueling fears of Soviet penetration into Europe. In this regard, on the eve of the election (on April 17) Alcide De Gasperi spoke about the election in Italy as a choice between freedom and Bolshevik totalitarianism. Nevertheless, despite the large-scale exploitation of the communist takeover in Prague in the anti-communist propaganda campaign, the Yugoslav diplomats in Rome disputed the influence of the coup d'etat in Czechoslovakia on the Italian election in 1948. Moreover, in their estimation, the dramatic events in Prague in February 1948 encouraged the "democratic masses" in Italy in the final weeks of the election campaign. ${ }^{17}$

In the so called Tripartite declaration, issued in March 1948, the USA, Great Britain and France called for ceding the whole Free Territory of Trieste/Territorio libero di Trieste (Zone A under Anglo-American and Zone B under Yugoslav administration) to Italy. The Yugoslav estimations of the impact of the Tripartite declaration on the outcome of the Italian election in 1948 were strikingly different. While the Yugoslav envoy in Rome Mladen Iveković argued that the right-wing parties in Italy failed to take advantage of this maneuver of the Western powers at the final stage of the election campaign, another prominent Yugoslav diplomat, Leo Mates, claimed in his book Međunarodni odnosi socijalističke Jugoslavije, that the Tripartite declaration of Washington, London and Paris doubtless influenced the election in Italy. ${ }^{18}$ At the meeting with a delegation of Italian workers, several weeks prior to the election, Josip Broz Tito called the Tripartite delegation an electoral trick, aimed at minimizing the Communist's chances of success. ${ }^{19}$

The Yugoslav legation in Rome perceived the Vatican as a pathfinder of the "forces of reaction" during the election campaign, underlining that the entire hierarchy of the Holy See, from Pope Pius XII to provincial priests and monks and nuns, engaged in the campaign for Christian Democrats. According to Yugoslav sources, the propaganda of the Catholic church during the election campaign was directed by car-

17 Ibid.

18 Leo Mates, Međunarodni odnosi socijalističke Jugoslavije, (Beograd: Nolit, 1976), 77.

19 Josip Broz Tito, Govori i članci, 3, (Zagreb: Naprijed, 1959), 261. 
dinal Luigi Lavitrano, prefect of the Sacred Congregation for Religious (Congregatio pro Institutis Vitae Consecratae et Societatibus Vitae Apostolicae), a congregation of the Curia entrusted with communication with orders, religious congregations and secular institutes. As stated in the report of the Yugoslav legation in Rome from April 1948, 67 Catholic women's orders took part in the election campaign including Suore di Santa Anna della Providenca, Suore Dominicane, Figlie di Maria as well as Figlie della Divina Providenca. Among the men's orders particularly active in the election campaign were: Dominicans, Carmelites, Conventual Franciscans, Capuchin Franciscans, Canons Regular of the Lateran and Augustinian Friars. Morover, during the election campaign priests were allowed to carry weapons. Apart from this structure, the Vatican participated in the election campaign through Comitato civico - an organ of the clerical propaganda, which, as stated in the Yugoslav report, had intensified its activities in early 1948 in the whole country. The Comitato civico controlled the activities of its local branches: Comitati civici diocesani and Comitati civici locali. According to Yugoslav sources, the Comitati civici were subordinated to the Azione Cattolica, i.e. to the Vatican. The report of the Yugoslav legation reads, that the Comitati civici were maintaining contacts with "fascist" groups and the police. The main task of the Comitati civici was persuading people to vote for the Christian Democracy. The authors of the Yugoslav report stressed that the activities of the Comitati civici had signaled full-scale mobilization of the Catholic forces in Italy for the Christian Democracy in the April election in Italy. The Yugoslav document underlined the role of Pope Pius XII, who actively took part in the anticommunist campaign, highlighting both the Pope's regular contacts with institutions of Catholic propaganda as well as his speeches on 10 March and 28 March in which he agitated for the victory of the Christian Democracy. His participation in the anti-communist campaign was illustrated with quotes from his speech delivered at the meeting with the Clergy of the Diocese of Rome on 10 March, in which Pope Pius XII explicitly called for voting for non-communist parties: "It is your right and duty to draw the attention of the faithful to the extraordinary importance of the upcoming election and to the moral responsibility that this entails for all those who have the right to vote (...) It is, in the present circumstances, a strict obligation for those who have the right, men and women, to take part in the election. Whoever abstains from it, especially out of indolence or cowardice, commits a grave sin, a mortal sin. Everyone has to vote according to the dictates of conscience. 
Now it is evident that the voice of conscience requires that every sincere Catholic votes for those candidates or for those lists of candidates, who offer truly sufficient guarantees for the respect for God and souls (...) according to the law of God and Christian moral doctrine." The role of the Vatican was not restricted to conducting extensive propaganda during the election campaign in 1948. As stated in the document of the Yugoslav legation in Rome, the Vatican was one of the biggest donors to the anti-communist campaign, alongside the Confindustria (Confederazione generale dell'industria italiana/General Confederation of Italian Industry), Confida (Confederazione Italiana degli Agricoltori), and last but not least the USA, which donated to the "Italian reaction" more than 20 billion liras. The funds were used for printing propaganda materials, organization of meetings, covering travel costs of political agitators, bribes etc. ${ }^{20}$

According to the report of the Yugoslav legation in Rome, during the election campaign the Catholic churches in Italy had been converted into centers of agitation for Christian Democracy, which included distribution of propaganda materials (brochures, leaflets) and political speeches delivered from the pulpits, in which Catholic priests were describing the election as voting for God or against God. Moreover, the priests were instructed not to give absolution to Democratic Front sympathizers. Propaganda and radicalization of believers were intensified by "miracles", which reminded the Yugoslav diplomats in Rome of Middle Ages. These psychological maneuvers were supplemented with less sophisticated tools. The Yugoslav diplomats in Italy informed the Ministry of Foreign Affairs in Belgrade that prior to the election Azione Catholica prepared tens of thousands electoral certificates (certificati ellectorali), which allegedly had been distributed to reliable people, so that they could vote multiple times. ${ }^{21}$

The Yugoslav diplomatic representatives in Rome obtained confidential information on preparations of Italian armed forces and the security apparatus for the post-election period: increasing the number of soldiers in all branches of the armed forces, firing unreliable personnel from the police and the army and placing "fascist elements" in important positions in the police, the Italian army and the Arma dei Carabinieri. Moreover, several weeks prior to the election the general staffs of the

20 AJ, 836, 1-3-b/332, Poslanstvo FNRJ (Rim), Izbori za parlament i senat 18. 4. 1948.

21 Ibid. 
Italian and French armies entered into a secret agreement on deploying French troops on the French-Italian border and their participation in suppressing potential communist uprising in Italy in the post-election period: "The main forces of the Italian army were concentrated on the so-called Gothic line in Northern Italy. In Rome, two divisions were on standby, one of which was a motorized carabinieri unit. Armed forces were deployed to other major Italian checkpoints and a precise plan was drawn up to deal with the situation on election day and its aftermath. The army and navy were on high alert. The Italian and French general staffs struck a secret agreement on the buildup of the French armed forces on the French-Italian border a few weeks prior to the election, so that the French armed forces in Northern Italy could intervene in the event of a workers' uprising. The forces of the Italian army, police and carabinieri were reinforced by a military organization led by the Comitati civici, as well as fascist squadrons which were (...) armed by the police."22 Besides, the Yugoslav diplomats in Rome stressed the repression against the Left, in particular in the Southern Italy, underlining the murder of 38 trade union activists in Sicily prior to the April election. ${ }^{23}$

The outcome of the 1948 Italian general election confirmed the deep pessimism of Yugoslav diplomats about the political future of the communist and worker's movement in the Apennine Peninsula. The Christian Democrats won roughly $48 \%$ of the vote, winning an absolute majority in both chambers of the Italian parliament: the Chamber of Deputies (Camera dei deputati) and the Senate. Their chief rival - the Popular Democratic Front (PCI\&PSI) - won 31 percent of the vote for the Chamber of Deputies and 30.8 percent of the vote for the Senate. The Socialist Unity (Unità Socialista) led by Giuseppe Saragat and Ivan Matteo Lombardo came in third, winning 7.1 percent of the vote for the Chamber of Deputies. ${ }^{24}$

\section{Ibid.}

23 Ibid.

241948 Italian general election - Chamber of Deputies, access date 1. 3. 2021, https:// elezionistorico.interno.gov.it/index.php?tpel=C\&dtel=18/04/1948\&tpa=I\&tpe $=A \& l e v 0=0 \& l e v s u t 0=0 \&$ es $0=S \& m s=S ; 1948$ Italian general election - Senate, access date 1. 3. 2021, https://elezionistorico.interno.gov.it/index.php?tpel=S\&dtel $=18 / 04 / 1948 \&$ tpa $=I \&$ tpe $=A \& l e v 0=0 \& l e v s u t 0=0 \&$ es $0=S \& \mathrm{~ms}=\mathrm{S}$ 
Election results (Chamber of Deputies/Camera dei deputati) ${ }^{25}$

\begin{tabular}{|l|c|c|}
\hline & $\begin{array}{c}\text { \% of the vote for the } \\
\text { Chamber of Deputies }\end{array}$ & Number of seats \\
\hline Christian Democracy & 48.51 & 305 \\
\hline Popular Democratic Front & 30.98 & 183 \\
\hline Socialist Unity & 7.07 & 33 \\
\hline National Bloc & 3.82 & 19 \\
\hline Monarchist National Party & 2.78 & 14 \\
\hline Italian Republican Party & 2.48 & 9 \\
\hline Italian Social Movement & 2.01 & 6 \\
\hline Others & 2.35 & 5 \\
\hline
\end{tabular}

In comparison with the 1946 election, two major leftist parties, the Communists and Socialists, lost roughly seven percent of the vote. On the other hand, the Christian Democrats got circa 13 percent more votes. The difference between the votes of Communists and Socialists in 1946 and 1948 went to Saragat's and Lombardo's Socialist Unity (Unità Socialista) ${ }^{26}$

The Yugoslav analysts argued that the defeat of the Popular Democratic Front in the 1948 election was not only a result of repression, propaganda, election manipulation and international maneuverer of "reaction", but also of certain tactical shortcomings of the Partito Comunista Italiano during the election campaign, which was branded as "opportunistic". For the purpose of illustration, the Yugoslav legation in Rome in its report from 26 March emphasized that the Democratic Front, being sure about its victory, organized only one strike in February and March. Moreover, the general strike to protest the violence against the trade union leaders in Sicily was only an hour long. In March and April, the report from 26 March reads, the election campaign of the communists and socialists was restricted to election conventions and statements. ${ }^{27}$

25 Ibid.

26 AJ, 836, 1-3-b/332, Izborni rezultati.

27 AJ, 836, 1-3-b/332, Poslanstvo FNRJ (Rim), Izbori za parlament i senat u Italiji, 18. 4. 1948. - The Yugoslav communist establishment disapproved of the strategy of the PCI even before the 1948 general election. At the conference of the communist parties in Szklarska Poręba (Poland) in September 1947, Politburo member Edvard Kardelj 
The Yugoslav legation in Rome strongly criticized the Democratic Front's tactics in dealing with Giuseppe Saragat's party, particularly in Northern Italy, a stronghold of the socialists prior to the schism in the Italian Socialist Party in 1947. Consequently, the Democratic Front came off worst in Northern Italy. In this regard, the Yugoslavs criticized mistakes of the Communist Party in compiling the electoral list of the Democratic Front, which included even those socialists who supported Giuseppe Saragat. Nevertheless, the Yugoslav diplomats in Rome underlined the good result of the Popular Democratic Front in Southern Italy, which they ascribed to the Front's correct policy towards the peasantry. ${ }^{28}$ In contrast to the criticism of the communists' political tactic, the Yugoslav diplomats in Rome stressed the success of the Christian Democrats to mobilize passive and uninterested voters as well as supporters of small "reactionary" parties. ${ }^{29}$

In a concise analysis of the consequences of the 1948 general election in Italy, the Yugoslav legation in Rome reflected on the aftermath of the political earthquake in Italy in April 1948. The Yugoslavs speculated that the new government would function as a Catholic "dictatorship", which would focus on the following issues:

- Unrestricted ties with the USA; Extension of American economic and strategic influence in Italy and Italy's absolute dependence on the USA;

- Joining the Brussels Treaty;

- Revision of military provisions of the Peace Treaty, which the Italian establishment considered a prerequisite for Italian participation in the Western block;

- Economic and political annexation of Trieste (Free Territory of Trieste) with the help of Anglo-American occupation forces;

fiercely attacked the PCI's idea of a peaceful transition from the capitalist system to socialism. Marco Galeazzi, Tito e Togliati. Tra identita nazionale e internazionalismo, (Roma: Carocci, 2005), 91-92; Совещания Коминформа. 1947, 1948, 1949. Документы и материалы, ред. Александр Чубарьян, Грант Адибеков, Л. Гибианский, А. Ди Бьяджо, С. Понс, (Москва, 1998), 192-201; Petar Dragišić, Saša Mišić, "I partiti comunisti italiano e jugoslavo durante il conflitto jugoslavosovietico del 1948-1949 nelle fonti diplomatiche jugoslave", Qualestoria 1/2017, 92-93.

28 AJ, 836, 1-3-b/332, Poslanstvo FNRJ (Rim), Izbori za parlament i senat u Italiji, 18. 4. 1948.

29 AJ, 836, 1-3-b/332, Politička situacija u Italiji posle izbora od 18. aprila (Rezime izveštaja Poslanstva FNRJ u Rimu od 7. maja 1948). 
- Formation of a Mediterranean block, consisting of Italy, Greece, Turkey, Egypt, and perhaps Spain, in which Italy, with the support of the USA, would play a leading role.

In spite of the defeat of the Democratic Front, the Yugoslav diplomatic representatives in Rome did not give up hope for the political future of Italian communists in the post-election period: "We have always viewed these Italian elections as only one stage in the struggle of the Italian democratic forces, which have preserved their key positions and managed to keep the most radical elements in their ranks. The Front's eight million votes, about six million of which for the PCI, are undoubtedly a serious force that can oppose the plans of the Vatican and American imperialism." In this regard, the Yugoslavs made several recommendations to the Italian comrades: consolidation of the Party through strengthening ties with the Socialist Party and "mobilization of masses", co-opting the national trade union (Italian General Confederation of Labour/Confederazione Generale Italiana del Lavoro) and National Association of Italian Partizans (Associazione Nazionale Partigiani d'Italia) into the Democratic Front, "unmasking the policy of the Vatican, the agent of American imperialism", preparations of the most militant Communist elements for the upcoming struggle as well as "dispelling the illusions about the parliamentary system". ${ }^{30}$

\section{Conclusion}

The convincing victory of the Christian Democracy in April 1948 paved the way to the consolidation of the anti-communist block in the Apennine Peninsula and Italy's irreversible pro-Western orientation. In May 1948 Alcide De Gasperi formed his fifth government, a dominantly right-wing coalition consisting of Christian Democracy, Saragat's Socialist Party of Italian Workers, Italian Republican Party and Italian Liberal Party. ${ }^{31}$

Six months after the general election Yugoslav envoy in Rome, Mladen Iveković, stressed that the outcome of the election had opened the door to the consolidation of a Catholic "dictatorship", with the help of the Vatican, Saragat's party, the Republicans and the Anglo-Americans. He warned of the coming "totalitarian system" in state administration, the world of high finance, and in public life in general. In this regard, the Yugoslav diplomat

30 Ibid.

31 Mammarela, L'Italia contemporanea, 133. 
emphasized that the representatives of the Christian Democracy had occupied the highest positions in Italian economy (industry, banks) and state institutions. Besides, he underlined the intensified meddling of the USA in Italian affairs, quoting CIA chief in Italy as saying that the American struggle against communists in Italy was not finished. In his report Iveković payed particular attention to the impact of the Vatican on Italian politics following the general election in April 1948 underscoring the activities of the Catholic Action (Azione Cattolica): "Catholic action, as the most powerful and best organized Catholic organization in Italy, imposes its policy and control in political, social and cultural life (...) The aim of Catholic action at this time is to stabilize the Catholic masses to fight against the forces of democracy (...) For the first time since the unification of the Italian people, the helm of the state is in the hands of people completely loyal to the Vatican and its policy." 32

The report of the Yugoslav legation in Rome also focused on the Italian Left (Communists and Neni's Socialists) in the post-election period. Mladen Iveković lamented the dissolution of the Democratic Front following the election, blaming the centrists and "right-wing elements" ("who were fulfilling the wishes of agents of bourgeoisie") for the breakup of the leftist coalition. However, Iveković's report underlined that the failed assassination of Palmiro Togliatti on 14 July 1948 and the subsequent general strike boosted the Party's self-confidence and improved the reputation of the PCI and its leader. Nevertheless, the Yugoslav diplomat stressed in his analysis the gravity of the political situation in Italy after the general election in April 1948 and the strategy of the establishment aimed at containing the Communist Party: "The plan of the reactionary and fascist circles in Italy is completely clear: to isolate the Communist Party, to stop the strengthening of the democratic forces, to push them from the positions they have acquired lately and to establish their unlimited political and economic power." 33

\section{Summary}

The general election in Italy in April 1948 was a watershed moment in the history of Italy after the Second World War. The convincing victory of the right-wing and centrist forces in Italy over the left-wing coalition consisting of socialists (Italian Socialist Party/Partito Socialista Ital-

32 AJ, 836, 1-3-b/332, Poslanstvo FNRJ (Rim) - Ministarstvu inostranih poslova FNRJ, 8. 11. 1948.

33 Ibid. 
iano) and communists (Italian Communist Party/Partito Communista Italiano) consolidated the anti-communist and thereby pro-Western block in the Appennine Peninsula. The containment of the Communist Party thus became one of the most distinctive features of the Italian political system during the Cold War era.

The Yugoslav diplomats in Rome were closely observing the election in Italy, focusing on the strategies of domestic (Communists, Socialists, Christian Democrats, the Vatican) as well as foreign protagonists in the Italian politics. The Yugoslav clear anti-Western orientation (prior to the Resolution of the Cominform and the Tito-Stalin split) profoundly shaped the attitude of the Yugoslav regime towards the 1948 Italian election. The reports of the Yugoslav legation in Rome expressed genuine sympathy for the Italian comrades, despite Yugoslav criticism of certain facets of the Communist strategy in the spring of 1948. On the other hand, the Yugoslavs vehemently condemned the anti-Communist policy of the Italian establishment and its domestic and international tutors. The dramatic tone in the Yugoslav documents reveals how much the Yugoslav diplomats were cognizant of the importance of the political earthquake in Italy in April 1948.

\section{Sources and Literature}

- $\quad$ Arhiv Jugoslavije: Kabinet maršala Jugoslavije (836); Centralni komitet Saveza komunista Jugoslavije (507).

- Broz, Josip Tito. Govori i članci, 3. Zagreb: Naprijed, 1959.

- Совещания Коминформа. 1947, 1948, 1949. Документы и материалы, ред. Александр Чубарьян, Грант Адибеков, Л. Гибианский, А. Ди Бьяджо, С. Понс. Москва, 1998.

- Dimitrijević, Bojan, Dragan Bogetić. Tršćanska kriza 1945-1954. Vojnopolitički aspekti. Beograd: Institut za savremenu istoriju 2009.

- Dragišić, Petar, Saša Mišić. "I partiti comunisti italiano e jugoslavo durante il conflitto jugoslavosovietico del 1948-1949 nelle fonti diplomatiche jugoslave". Qualestoria 1/2017, 89-101.

- Dragišić, Petar. “Tito's War after the War: Yugoslav Territorial Claims against Austria and Italy, 1945-1949". The Alps-Adriatic Region. International and Transnational Perspectives on a Conflicted European Region, eds Wolfgang Mueller, Karlo Ruzicic-Kessler, Philipp Greilinger, 31-51. Wien: New Academic Press, 2018.

- Dragišić, Petar. Šta smo znali o Italiji. Pogledi iz Beograda na Italiju 19551978. Beograd: Institut za noviju istoriju Srbije, 2019. 
- Galeazzi, Marco. Tito e Togliati. Tra identita nazionale e internazionalismo. Roma: Carocci, 2005.

- Ginsborg, Paul. Storia d'Italia dal dopoguerra a oggi. Torino: Piccola Biblioteca Einaudi Storia, 2006

- $\quad$ Lekić, Miodrag. Istorija Italije. Od Kavura do Montija (1861-2011). Beograd: Smart studio, 2013.

- $\quad$ Mammarella, Giuuseppe. L'Italia contemporanea (1943-2011). Bologna: Società editrice il Mulino, 2012.

- Mates, Leo. Međunarodni odnosi socijalističke Jugoslavije. Beograd: Nolit, 1976.

- $\quad$ Milkić, Milan. „Jugoslovensko poslanstvo u Rimu 1947-1951“. Jugoslovenska diplomatija 1945-1961, zbornik radova, ur. Slobodan Selinić, 115-134. Beograd: Institut za noviju istoriju Srbije, 2012.

- Milkić, Miljan. Tršćanska kriza u vojno-političkim odnosima Jugoslavije sa velikim silama 1943-1947. Beograd: Institut za noviju istoriju Srbije, 2012.

- $\quad$ Mišić, Saša. Pomirenje na Jadranu. Jugoslavija i Italija na putu ka Osimskim sporazumima iz 1975. godine. Beograd: Fakultet političkih nauka, 2018.

- $\quad$ Novak, Bogdan C. Trieste 1941-1954. La lotta politica, etnica e ideologica. Mursia, 2013.

- $\quad$ Rolandi, Francesca. Con ventiquattromila baci. L'influenza della cultura di massa italiana in Jugoslavia (1955-1965). Bologna: Bononia University Press, 2015.

- Woller, Hans. Geschichte Italiens im 20. Jahrhundert. München: C. H. Beck, 2010. 


\title{
Резиме
}

Петар Драгишић

\section{Југославија и општи избори у Италији 1948.}

\begin{abstract}
АпстРАкт: Чланак анализира југословенске перцепције општих избора у Италији 1948. године. Истраживање је фокусирано пре свега на извештаје југословенског посланства у Риму, које је интензивно пратило предизборну кампању, као и последице ове прекретнице у хладноратовској историји Италије. Југословенски извори тиме значајно осветљавају стратегије главних протагониста политичких догађања у Италији априла 1948. године.

КљУчНЕ РЕчИ: избори, 1948, Италија, Југославија, Тољати
\end{abstract}

Избори у Италији у пролеће 1948. представљали су прекретницу у послератној историји Италије. Победа деснице и снага центра над левом коалицијом, коју су чиниле Комунистичка партија Италије и Социјалистичка партија Италије, представљала је пресудни корак ка стабилизацији антикомунистичког и прозападног блока на Апенинском полуострву.

У Југославији су избори 1948. пажљиво праћени, при чему су посебно биле анализиране стратегије домаћих (комунисти, социјалисти, демохришћани, Ватикан), као и иностраних протагониста у италијанској политици. Ове анализе и процене су биле снажно прожете југословенском антизападном оријентацијом током првих послератних година. У извештајима југословенске амбасаде у Риму доминирале су нескривене симпатије према Комунистичкој партији Италије, упркос одређеним неслагањима са стратегијом италијанских комуниста у том периоду. С друге стране, југословенски посматрачи и дипломате снажно су осуђивали антикомунистичку политику италијанског естаблишмента и његових међународних тутора. Драматични тонови у анализираним југословенским документима откривају да су југословенске дипломате исправно перципирале важност општих избора у Италији априла 1948. године. 